\title{
SOLID PHASE EXTRACTION AND PRECONCENTRATION OF Ni(II) USING 1-(2-PYRIDYLAZO)-2-NAPHTHOL) (PAN) MODIFIED $\beta$-CYCLODEXTRIN BUTANEDIOL DIGLYCIDYL ETHER POLYMER AS A SOLID PHASE EXTRACTANT
}

\author{
Sandeep Jaggi, Usha Gupta \\ Department of Chemistry, Punjabi University, Patiala (India) \\ ushagupta_doc@yahoo.co.in
}

\begin{abstract}
A sensitive, simple and selective preconcentration method was developed for the preconcentration of trace amounts of $\mathrm{Ni}(\mathrm{II})$ ions using 1-(2-pyridylazo)-2-naphthol (PAN) modified $\beta$-cyclodextrin butanediol diglycidyl ether polymer as a solid phase extractant. Potential factors affecting the sorption of Ni(II) were investigated. Meanwhile, the optimum conditions were established. The sorbed Ni(II) was eluted using $5 \mathrm{ml}$ of $2 \mathrm{M} \mathrm{HCl}$. The preconcentration factor was 70 . The detection limit for Ni(II) was $1.18 \mathrm{ng} / \mathrm{ml}$. The relative standard deviation (RSD \%) was $<1 \%$. The developed method was successfully applied for the determination of trace $\mathrm{Ni}$ (II) in different water and potato chip samples as well as reference alloy samples.
\end{abstract}

Keywords: $\beta$-cyclodextrin polymer; Ni(II); preconcentration; 1-(2-pyridylazo)-2-naphthol

\section{ЕКСТРАКЦИЈА И ПРЕКОНЦЕНТРАЦИЈА ВО ЦВРСТА ФАЗА НА Ni(II) CO МОДИФИЦИРАН ПОЛИМЕР НА $\beta$-ЦИКЛОДЕКСТРИН-БУТАНДИОЛ-ДИГЛИЦИДИЛ- ЕТЕР СО 1-(2-ПИРИДИЛАЗО)-2-НАФТОЛ) (РАN) КАКО ЕКСТРАКТОР ВО ЦВРСТАТА ФАЗА}

Беше развиен едноставен селективен метод со преконцентрација на траги од јони на $\mathrm{Ni}(\mathrm{II})$ користејќи модифициран полимер на $\beta$-циклодекстрин-бутандиол-диглицидил етер со 1-(2-пиридилазо)-2-нафтол) (PAN) како екстрактор во цврста фаза. Беа испитувани потенцијалните фактори кои влијаат на сорпцијата на Ni(II). Во исто време се определени оптималните услови за екстракција. Сорбираниот Ni(II) беше изделен со $5 \mathrm{ml} 2 \mathrm{MHCl}$. Добиениот фактор на преконцентрација изнесува 70. Границата на детекција за $\mathrm{Ni}(\mathrm{II})$ е $1,18 \mathrm{ng} / \mathrm{ml}$. Релативната стандардна девијација (RSD $\%$ е е $<1 \%$. Развиениот метод беше успешно применет за определување траги на $\mathrm{Ni}(\mathrm{II})$ во примероци вода и чипс од компир, како и во легури.

Клучни зборови: полимер на $\beta$-циклодекстрин; $\mathrm{Ni}(\mathrm{II})$; преконцентрација; 1 -(2-пиридилазо)-2-нафтол

\section{INTRODUCTION}

Nickel is a siderophile element; its abundance in average crustal rocks is $75 \mathrm{mg} \mathrm{g}^{-1}$. Nickel can be released into the atmosphere from several industrial processes, including oil- and coal-burning power plants, trash incinerators and the metallurgy industry. Although nickel is considered an essential element, which acts as an activator of several enzymes to enhance insulin activity, excessive nickel in the organism is very toxic, which can be manifested by effects on the activity of natural killer cells [1]. Preconcentration is commonly used if the concentration of trace elements in a sample is lower than the detection limit of an analytical technique. Furthermore, a number of interfering constituents can be removed using 
preconcentration procedures. The literature reports several preconcentration procedures such as liquid-liquid extraction [2], micellar mediated extraction [3], coprecipitation [4], cloud point extraction [5], electrochemical methods [6] and solid phase extraction [7]. Disadvantages such as significant chemical additives, solvent losses, complex equipments, considerable secondary waste, prefiltration problems and time-consuming procedures limit the application of most of these techniques. Solid phase extraction, however, solves this problem as it offers several advantages. These include: (1) high enrichment factors; (2) short extraction times; (3) minimal costs due to low consumption of reagents; (4) absence of emulsion; (5) ease of automation; (6) safety with respect to hazardous samples; and (7) high selectivity. This technique is also attractive as there is no need to use organic solvents, which may cause toxic effects. An actual tendency in the field of solid-phase preconcentration is related to the adoption of new sorbent materials with exceptional performance, such as high chemical resistance, selectivity, large surface area, and obviously, high sorption capacity. An important strategy for metal enrichment is the incorporation of complexing reagents in solid supports. 1-(2-Pyridylazo)-2-naphthol (PAN) is a versatile organic chromogenic reagent that forms complexes with a variety of transition metals in different $\mathrm{pH}$ ranges and with different adsorbents. There are many studies that have reported the use of PAN-modified solid supports in the preconcentration of metal ions [8-19]. The other advantage of PAN is the absence of its affinity for alkali and alkaline earth metal ions.

The purpose of the present study was to assess the feasibility of using 1-(2-pyridylazo)2-naphthol modified $\beta$-cyclodextrin butanediol diglycidyl ether polymer as a solid phase extractant for the preconcentration and determination of $\mathrm{Ni}(\mathrm{II})$ at $\mathrm{ng} / \mathrm{ml}$ levels in different samples.

\section{EXPERIMENTAL}

\subsection{Materials and methods}

All reagents used were of analytical reagent grade. Double distilled water was used throughout the experiment. The Ni(II) solution was prepared by dissolving $0.237 \mathrm{~g}$ of nickel chloride hexahydrate $\left[\mathrm{NiCl}_{2} \cdot 6 \mathrm{H}_{2} \mathrm{O}\right]$ in $100 \mathrm{ml}$ of distilled water to give a standard stock solution of $4 \times 10^{-6} \mathrm{~mol} / \mathrm{l}$. The solution of the PAN reagent was prepared by dissolving an appropriate amount of PAN (Fluka Chemical Company) in N,N-dimethylformamide. 1,4-Butanediol diglycidyl ether was obtained from Sigma Aldrich (USA). $\beta$-Cyclodextrin was obtained from SD Fine Chemicals Ltd. (Mumbai, India). Buffer solutions were hydrochloric acid/sodium acetate for $\mathrm{pH}$ 2.0-3.5, sodium acetate/acetic acid for $\mathrm{pH}$ 4.0-6.5 and ammonia/ammonium chloride for $\mathrm{pH} 8-11$. Glassware was washed with chromic acid and soaked in 5\% nitric acid and rinsed with double distilled water before use.

\subsection{Apparatus}

A Shimadzu UV-1800 spectrophotometer (Shimadzu Ltd., Japan) equipped with matched $10 \mathrm{~mm}$ quartz cells was used to measure absorbance. All pH measurements were performed using a Digital Century CP 901 $\mathrm{pH}$ meter with a combined glass electrode. A thermostatic shaking water bath (Perfit India Ltd.) was used to carry out all the procedures.

\subsection{Sample collection and conditioning}

Water samples were collected from different parts of Patiala City. The water samples were immediately filtered through a cellulose membrane filter $(0.45 \mathrm{~nm}$ pore size $)$ and stored in precleaned polyethylene bottles. Next, the $\mathrm{pH}$ of the sample was adjusted to 9.5 and the preconcentration procedure was applied as described above. 


\subsection{Determination of $\mathrm{Ni}(I \mathrm{I})$ in different potato chip samples}

Potato chips of selected brands that were available locally were purchased for further processing. Wet digestion of the chips was carried out by digesting $0.5 \mathrm{~g}$ of each sample with a mixture of $\mathrm{HNO}_{3}: \mathrm{H}_{2} \mathrm{SO}_{4}(8: 4)$. This mixture was heated up to $130{ }^{\circ} \mathrm{C}$ for $1 \mathrm{~h}$. After cooling, $5 \mathrm{ml}$ of distilled water was added to the sample and mixed. The residue was filtered. The sample was then diluted to $100 \mathrm{ml}$ with distilled water. An aliquot of the above sample was taken and spiked with a known amount of $\mathrm{Ni}$ (II) and assayed using the general procedure.

\subsection{Determination of $\mathrm{Ni}(\mathrm{II})$ in standard alloys}

The accuracy of the proposed method was verified by the determination of ions in standard reference alloy samples. $0.1 \mathrm{~g}$ of the standard alloy was completely dissolved in 20 $\mathrm{ml}$ of hydrochloric acid by heating on a water bath; $2 \mathrm{ml}$ of $30 \%$ hydrogen peroxide was added to the solution. The excess of peroxide was decomposed by heating the solution in a water bath. The solution was cooled, filtered and diluted to $100 \mathrm{ml}$ with double distilled water. Further dilutions were made as required. An aliquot of this solution was taken and preconcentration was performed by the procedure described below.

\subsection{Procedure}

\subsubsection{Synthesis of $\beta$-cyclodextrin butanediol diglycidyl ether polymer $(\beta-C D B P)$}

$\beta$-CDBP was synthesized by a previously published method [20]. A brief procedure for the synthesis is mentioned here. $20 \mathrm{~g}$ of $\beta-\mathrm{CD}$ were dissolved in $50 \mathrm{ml}$ of $20 \% \mathrm{NaOH}$. To this was added $20 \mathrm{ml}$ of butanediol diglycidyl ether dropwise. The polymer was formed in $1.5 \mathrm{~h}$ and dried in a vacuum at $90^{\circ} \mathrm{C}$. The polymer was ground and sieved into $<60,60-80,80-100$ and $>100$ mesh fractions. The 80-100 mesh fraction was washed with double distilled water five to six times. Then, the polymer was dried again under vacuum at $90{ }^{\circ} \mathrm{C}$ and kept at room temperature $\left(25^{\circ} \mathrm{C}\right)$ in a dessicator.

\subsubsection{Inclusion of $P A N$ in the $\beta-C D B P$ cavity to form the $\beta$-CDBP-PAN modified polymer}

$5.0 \mathrm{~g}$ of the synthesized polymer, $\beta$-CDBP (80-100 mesh size), was placed in a $250 \mathrm{ml}$ stoppered conical flask. To this was added 10 $\mathrm{ml}$ of $9.0 \mathrm{pH}$ buffer solution and the polymer was allowed to swell for 15 minutes. A fixed volume of $4 \times 10^{-6} \mathrm{~mol} / \mathrm{l}$ solution of PAN was added to the treated polymer and made up to 50 $\mathrm{ml}$ with distilled water. This was shaken for two hours. The colored polymer was washed with distilled water and vacuum dried at $100^{\circ} \mathrm{C}$. The modified polymer was stored in a dessicator until use.

\subsubsection{Batch extraction procedure}

At room temperature, i.e. $30^{\circ} \mathrm{C}, \beta$-CDBPPAN (500 mg) and $10.0 \mathrm{ml}$ of buffer solution $(\mathrm{pH} 9.5)$ were added to a $100 \mathrm{ml}$ stoppered conical flask. The mixture was allowed to stand for approximately $15 \mathrm{~min}$ so that $\beta$-CDBP-PAN could be swollen sufficiently. $100 \mathrm{ng} / \mathrm{ml}$ of $\mathrm{Ni}$ (II) was added and made up to $100 \mathrm{ml}$ with double distilled water. After the mixture was shaken in the thermostatic shaking water bath for $40 \mathrm{~min}, 5.0 \mathrm{ml}$ of the supernatant solution was transferred into a $10 \mathrm{ml}$ volumetric flask and the absorbance was measured using a standard spectrophotometric method [21].

\subsubsection{Elution of $\mathrm{Ni}(\mathrm{II})$}

$\mathrm{Ni}(\mathrm{II})$ retained on the $\beta$-CDBP-PAN polymer was eluted using $5 \mathrm{ml}$ of $2 \mathrm{M} \mathrm{HCl}$. Eluted $\mathrm{Ni}$ (II) was assessed using a standard spectrophotometric method [21]. 


\subsubsection{Regeneration of the polymer}

The polymer was regenerated by dipping it in $10.0 \% \mathrm{TX}-100(w / v)$ for $1 \mathrm{~h}$ and then washing with distilled water. $\beta$-CDBP was further treated with $\mathrm{HNO}_{3}$ and was finally washed with distilled water to neutral conditions.

\section{RESULTS AND DISCUSSION}

\subsection{Sorption of $\mathrm{Ni}(\mathrm{II})$ as a function of $\mathrm{pH}$}

For the solid phase extraction of heavy metal ions on different types of chelating resins, the $\mathrm{pH}$ of the aqueous solution is one of the foremost factors for quantitative recovery of the analyte [22]. Therefore, the effect of $\mathrm{pH}$ on the sorption of $\mathrm{Ni}$ (II) on the PAN-modified polymer was studied in the $\mathrm{pH}$ range of $4.5-$ 10.5. For this purpose, $100 \mathrm{ng} / \mathrm{ml}$ of $\mathrm{Ni}(\mathrm{II})$ was spiked in $100 \mathrm{ml}$ of the model solution and the $\mathrm{pH}$ of this solution was adjusted using different buffer solutions, then the general preconcentration procedure was followed. The correlation between the $\%$ sorption of $\mathrm{Ni}(\mathrm{II})$ on the resin and $\mathrm{pH}$ is presented in Fig. 1. The results of this study show that quantitative sorption ( $\geq 95 \%)$ of $\mathrm{Ni}$ (II) ions was achieved over the $\mathrm{pH}$ range of 8.5-10.5. Therefore, for subsequent experiments, $\mathrm{pH} 9.5$ was selected as the working $\mathrm{pH}$.

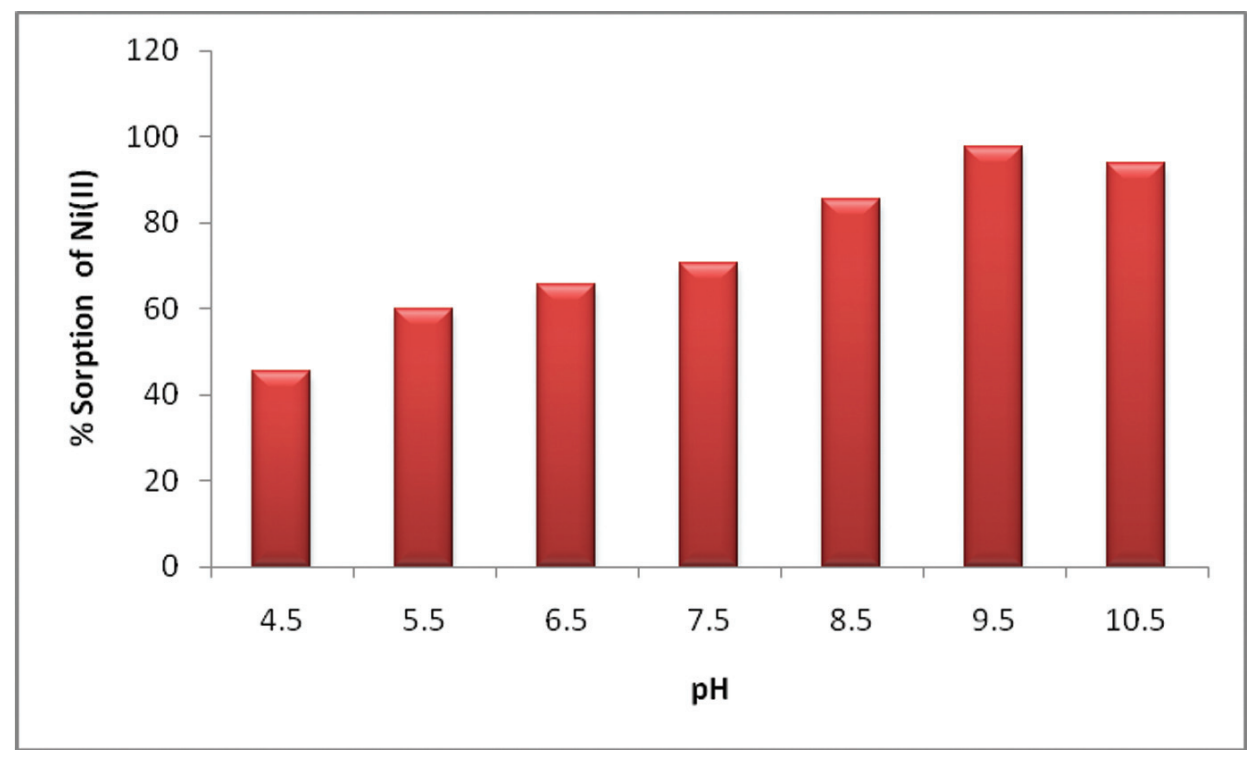

Fig. 1. Effect of $\mathrm{pH}$ on the sorption of $\mathrm{Ni}(\mathrm{II})$ on PAN-loaded $\beta$-CDBP polymer $\left(100 \mathrm{ng} / \mathrm{ml}\right.$ of $\mathrm{Ni}(\mathrm{II}) ; 500 \mathrm{mg}$ of the resin; $100 \mathrm{ml}$ sample volume; temperature $25^{\circ} \mathrm{C}$ )

\subsection{Effect of the amount of adsorbent (bed height)}

The amount of solid phase extractant material is another imperative factor in sorption studies for the quantitative recovery of metal chelates [23]. Quantitative retention $(\geq 95 \%)$ cannot be achieved when the resin is less than the optimum amount. On the other hand, an excess amount of resin prevents the quantitative elution of the retained metal chelate by a small volume of the eluent. In order to optimize the smallest amount of extractant, 100, 200, 300, 400, 500, 600 and $700 \mathrm{mg}$ of the resin were added to the same volume of the synthetic solution containing $100 \mathrm{ng} / \mathrm{ml}$ of $\mathrm{Ni}(\mathrm{II})$ and preconcentrated by the general procedure. Quantitative recoveries were obtained with $500 \mathrm{mg}$ or more of resin (Figure 2). Therefore, $500 \mathrm{mg}$ of the resin was used for subsequent experiments. 


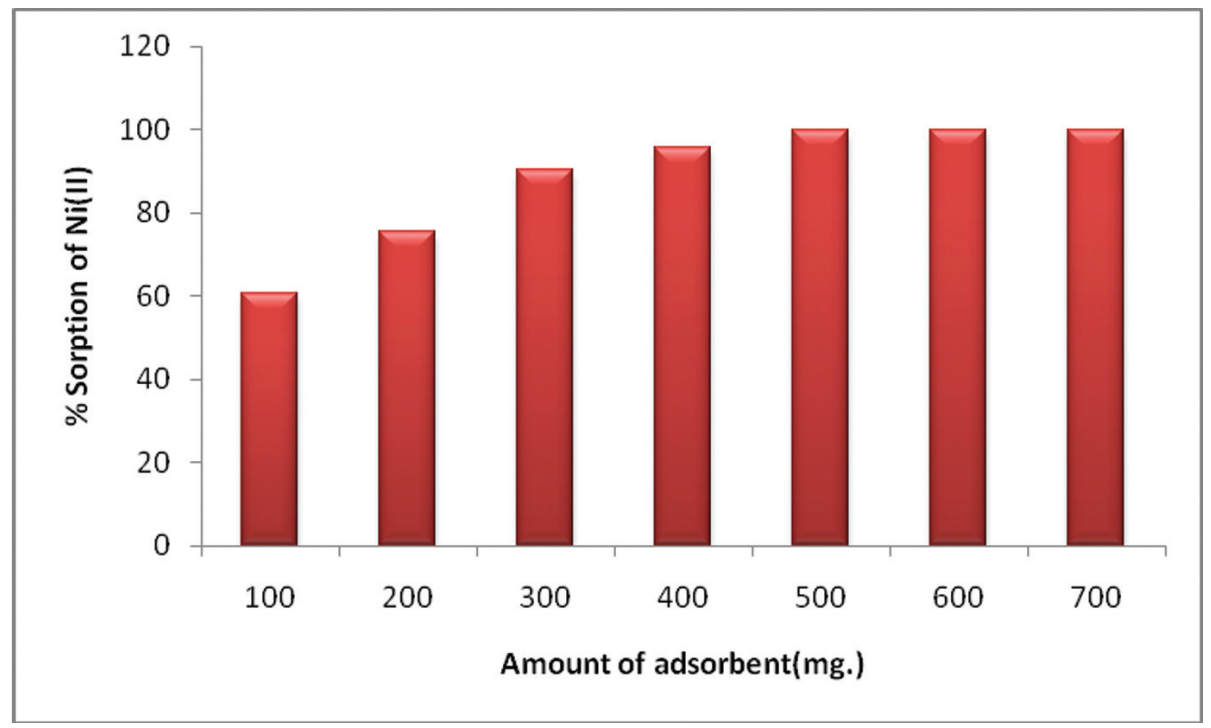

Fig. 2. Effect of the amount of the chelating resin on the sorption of $\mathrm{Ni}(\mathrm{II})$ (100 ng/ml of $\mathrm{Ni}(\mathrm{II}) ; \mathrm{pH} 9.5 ; 100 \mathrm{ml}$ sample volume; temperature $25^{\circ} \mathrm{C}$ )

\subsection{Kinetics of metal sorption}

The kinetics of metal sorption is an important factor in determining the possibility of application of the $\beta$-CDBP-PAN polymer for the selective uptake of $\mathrm{Ni}(\mathrm{II}) .500 \mathrm{mg}$ of the resin were shaken with $100 \mathrm{ml}$ of the solution containing $100 \mathrm{ng} / \mathrm{ml}$ of $\mathrm{Ni}$ (II) at room temperature for different contact times ranging from 20 to $70 \mathrm{~min}$. The loading half time $\left(t_{1 / 2}\right)$ needed to reach $50 \%$ sorption of the total loading capacity (estimated from Figure 3) was found to be less than $20 \mathrm{~min}$. The kinetics of the resin-metal interaction is sufficiently rapid for $\mathrm{Ni}$ (II) at the optimum $\mathrm{pH}$. The faster uptake of $\mathrm{Ni}(\mathrm{II})$ on $\beta$-CDBP-PAN reflects a good accessibility of the chelating resin sites to metal ions. Therefore, contact time of $40 \mathrm{~min}$ was selected as the sorption equilibrium time.

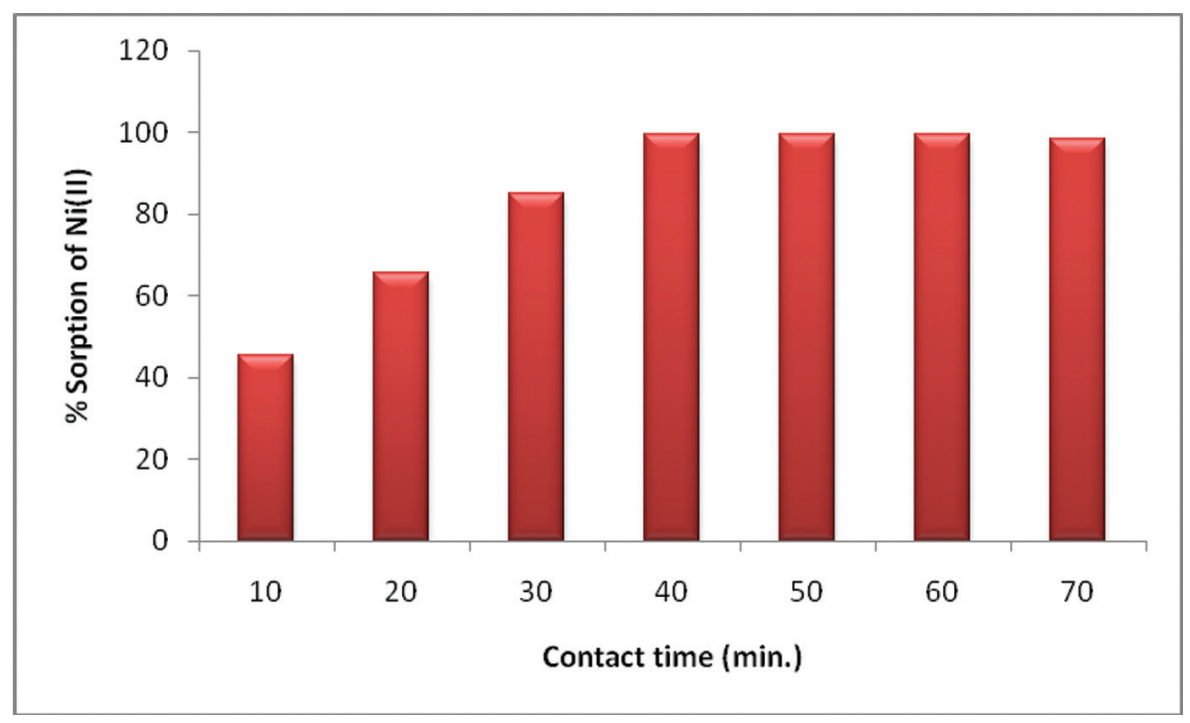

Fig. 3. Kinetics of Ni(II) sorption on PAN loaded $\beta$-CDBP polymer (100 ng/ml of $\mathrm{Ni}(\mathrm{II}) ; \mathrm{pH} 9.5 ; 500 \mathrm{mg}$ of resin; $100 \mathrm{ml}$ sample volume; temperature $25^{\circ} \mathrm{C}$ ) 


\subsection{Effect of the sample volume}

In order to explore the possibility of enriching a low concentration of analyte from a large volume of solution, the effect of sample volume on the retention of $\mathrm{Ni}$ (II) ions was also investigated. For this purpose, $25,50,100,150,200,250,300,350,400$ and
$450 \mathrm{ml}$ of sample solutions containing 100 $\mathrm{ng} / \mathrm{ml}$ were assayed. Quantitative sorption $(\geq 95 \%)$ was obtained for a sample volume less than $350 \mathrm{ml}$ (Figure 4). Therefore, a sample volume of $100 \mathrm{ml}$ was adopted for the preconcentration of the analyte from sample solutions.

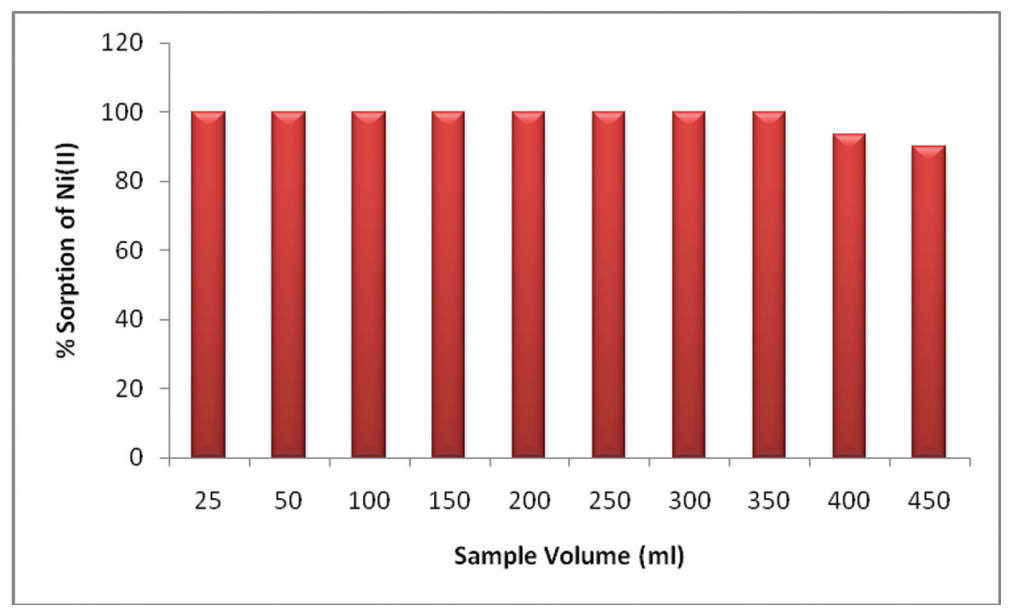

Fig. 4. Effect of the sample volume on the sorption of $\mathrm{Ni}(\mathrm{II})$ (100 ng/ml of $\mathrm{Ni}(\mathrm{II}) ; \mathrm{pH} 9.5 ; 500 \mathrm{mg}$ of resin; contact time $40 \mathrm{~min}$; temperature $25^{\circ} \mathrm{C}$ )

\subsection{Effect of the eluent concentration and its volume}

Various concentrations of hydrochloric acid were examined to obtain quantitative recovery values for $\mathrm{Ni}$ (II) from the chelating resin. The recovery values were not quantitative when the

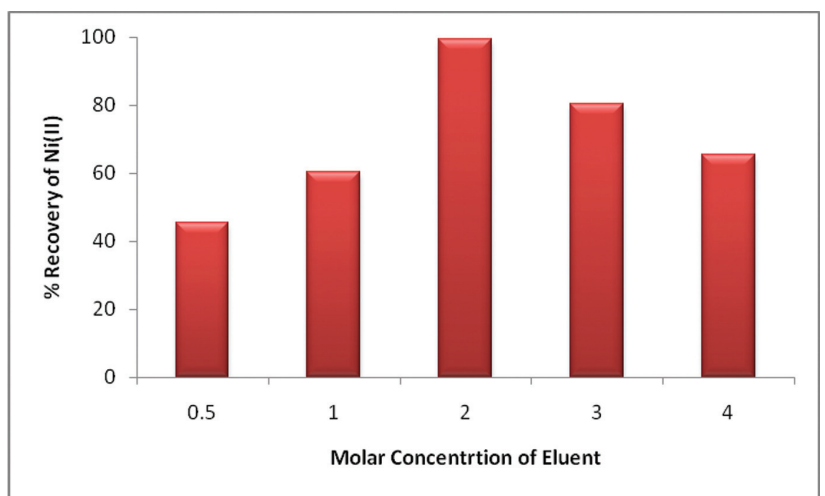

Fig. 5. Effect of the molar concentration $\mathrm{HCl}$ on the elution of $\mathrm{Ni}(\mathrm{II})(100 \mathrm{ng} / \mathrm{ml}$ of $\mathrm{Ni}(\mathrm{II}) ; \mathrm{pH} 9.5 ; 500 \mathrm{mg}$ of resin; $100 \mathrm{ml}$ sample volume; contact time $40 \mathrm{~min}$; temperature $25^{\circ} \mathrm{C}$ ) concentration of $\mathrm{HCl}$ was $<2 \mathrm{M}>$ used as an eluent. Therefore, $2 \mathrm{M} \mathrm{HCl}$ was used for quantitative recovery of $\mathrm{Ni}$ (II) from the $\beta$-CDBP-PAN polymer in further studies. The volume of the eluent $(2 \mathrm{M} \mathrm{HCl})$ that can completely strip the retained $\mathrm{Ni}$ (II) from the solid phase is an important parameter for obtaining the maximum pre-

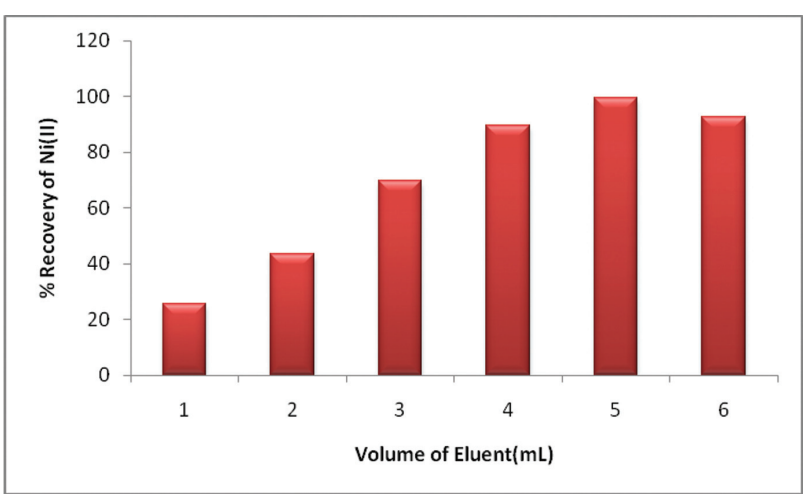

Fig. 6. Effect of the volume of $\mathrm{HCl}$ on the elution of $\mathrm{Ni}(\mathrm{II})(100 \mathrm{ng} /$ $\mathrm{ml}$ of $\mathrm{Ni}(\mathrm{II}) ; \mathrm{pH} 9.5 ; 500 \mathrm{mg}$ of resin; $100 \mathrm{ml}$ sample volume; contact time $40 \mathrm{~min}$; temperature $25^{\circ}$ ) 
concentration factor. Thus, some experiments were carried out in order to choose the proper eluent volume for stripping $\mathrm{Ni}(\mathrm{II})$ ions from the chelating resin (Figures 5 and 6). The recovery values for $\mathrm{Ni}$ (II) ions from the chelating resin were greater than $95 \%$ in the eluent volume range of 4-6 ml. Thus, an eluent volume of $5 \mathrm{ml}$ was selected for further studies. The preconcentration factor was found to be 70 if the volume of eluent used was $5 \mathrm{ml}$.

\subsection{Matrix effects}

The preconcentration procedure for trace metals can be strongly affected by other constituents of the sample. For this reason, the reliability of the proposed method was examined in the presence of possible interfering ions. Interfering cations and anions were added to the model samples. Table 1 shows the tolerance limit of interfering ions to $\mathrm{Ni}(\mathrm{II})$.

Table 2
T a b 1 e 1

The effect of foreign ions on the determination of $100 \mathrm{ng} / \mathrm{ml}$ of $\mathrm{Ni}(\mathrm{II})$

\begin{tabular}{lc}
\hline \hline Foreign ions & $\begin{array}{l}\text { Tolerance limit } \\
\text { [WForeign ion/ } \\
\text { WNi(II)] }\end{array}$ \\
\hline $\mathrm{NO}_{3}{ }^{-}, \mathrm{SO}_{4}{ }^{2-}, \mathrm{HPO}_{4}{ }^{2-}, \mathrm{SCN}^{-}, \mathrm{NO}_{2}^{-}, \mathrm{PO}_{4}{ }^{3-}$ & $>1000$ \\
$\mathrm{Na}^{+}, \mathrm{K}^{+}, \mathrm{Mg}^{2+}, \mathrm{Ba}^{2+}, \mathrm{Al}^{3+}, \mathrm{Rb}^{+}, \mathrm{Cs}^{+}, \mathrm{Ag}^{+}$ & 1000 \\
$\mathrm{Sb}^{3+}, \mathrm{Ca}^{2+}, \mathrm{Zr}^{4+}, \mathrm{Ti}^{3+}$ & 500 \\
$\mathrm{Th}^{4+}, \mathrm{Sn}^{2+}, \mathrm{As}^{3+}$ & 100 \\
${ }^{a} \mathrm{Fe}^{3+},{ }^{b} \mathrm{Cu}^{2+},{ }^{c} \mathrm{Co}^{2+}$ & 10 \\
${ }^{d} \mathrm{Hg}^{2+},{ }^{d} \mathrm{Cd}^{2+},{ }^{e} \mathrm{~Pb}^{2+},{ }^{f} \mathrm{Fe}^{2+},{ }^{g} \mathrm{Mn}^{2+}$ & 1 \\
$\mathrm{EDTA}^{2+} \mathrm{Br}^{-}, \mathrm{F}^{-}, \mathrm{CN}^{-}$, citrate & 1 \\
\hline \hline
\end{tabular}

${ }^{a}$ Masked with $1.0 \mathrm{ml}$ of $5.0 \%$ ammonium oxalate solution; ${ }^{b}$ Masked with $1.0 \mathrm{ml}$ of $3.0 \%$ sodium thiosulphate; ${ }^{c}$ masked with $1.0 \mathrm{ml}$ of $10.0 \% \alpha$-benzilmonoxime;

${ }^{d}$ masked with $5.0 \mathrm{ml}$ of $2.0 \%$ sodium thioglycollate solution; ${ }^{e}$ masked with $2.0 \mathrm{ml}$ of $1.0 \%$ sodium sulfate solution; ${ }^{f}$ masked with $1.0 \mathrm{ml}$ of $2.0 \%$ 1,10-phenenthroline;

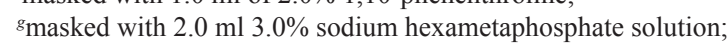
masked with $1.0 \mathrm{ml}$ of $10.0 \%$ sodium citrate solution.

\subsection{Total sorption capacity}

The capacity of the resin determined according to [24] was found to be of $29.05 \mu \mathrm{g} / \mathrm{g}$ of dry $\beta$-CDBP-PAN resin.

Various parameters studied for the preconcentration of Ni(II) using $\beta-C D B P-P A N$ modified polymer as the sold phase extractant

\begin{tabular}{ll}
\hline \hline Parameters & $\mathrm{Ni}(\mathrm{II})$ \\
\hline $\mathrm{pH}$ & 9.5 \\
Shaking time & $40 \mathrm{~min}$ \\
Sample volume & $100 \mathrm{ml}$ \\
Adsorbent dose & $500 \mathrm{mg}$ \\
Mesh size of the polymer & $80-100$ \\
Eluent used & $\mathrm{HCl}$ \\
Eluent concentration & $2 \mathrm{M}$ \\
Volume of eluent used for elution & $5 \mathrm{ml}$ \\
Preconcentration factor & 70 \\
Sorption capacity & $29.05 \mu \mathrm{g} / \mathrm{g}$ of resin \\
Limit of detection & $1.18 \mathrm{ng} / \mathrm{ml}$ \\
Relative standard deviation & $<1 \%$ \\
Limit of quantification & $3.7 \mathrm{ng} / \mathrm{ml}$ \\
\hline \hline
\end{tabular}




\section{APPLICATIONS OF THE METHOD}

The method was applied to the determination of $\mathrm{Ni}(\mathrm{II})$ in water, potato chip samples and certified alloy samples. The results are shown in Tables 3, 4 and 5, respectively.

T a b le 3

Determination of Ni(II) in different water samples

\begin{tabular}{lcccc}
\hline \hline $\begin{array}{l}\text { Water } \\
\text { samples }\end{array}$ & $\begin{array}{c}\text { Spiked }(\mathrm{ng} / \mathrm{ml}) \\
\mathrm{Ni}(\mathrm{II})\end{array}$ & $\begin{array}{c}\text { Found }(\mathrm{ng} / \mathrm{ml}) \\
\mathrm{Ni}(\mathrm{II})^{a}\end{array}$ & $\begin{array}{c}\text { Relative } \\
\text { error } \%\end{array}$ & $\begin{array}{c}\text { Recovery } \\
\%\end{array}$ \\
\hline \multirow{3}{*}{ Tap water } & 0.0 & 11.6 & -- & -- \\
& 70.0 & $83.7 \pm 0.36$ & -3.00 & 103.0 \\
\hline \multirow{3}{*}{ Rose water } & 55.5 & $68.8 \pm 0.21$ & -3.06 & 103.0 \\
& 0.0 & $\mathrm{~N} . \mathrm{D}$. & -- & -- \\
& 60.0 & $62.1 \pm 0.26$ & -3.5 & 103.5 \\
Bore water & 50.0 & $51.7 \pm 0.21$ & -3.4 & -- \\
& 0.0 & 15.7 & -- & 103.4 \\
\hline \hline
\end{tabular}

${ }^{a}$ Mean \pm standard deviation

Table 4

Determination of Ni(II) in potato chip samples

\begin{tabular}{lcccc}
\hline \hline Sample & $\begin{array}{c}\text { Spiked (ng/ml) } \\
\mathrm{Ni}(\mathrm{II})\end{array}$ & $\begin{array}{c}\text { Found }(\mathrm{ng} / \mathrm{ml}) \\
\mathrm{Ni}(\mathrm{II})^{a}\end{array}$ & $\begin{array}{c}\text { Relative } \\
\text { error \% }\end{array}$ & $\begin{array}{c}\text { Recovery } \\
\%\end{array}$ \\
\hline American sour & 75.0 & $74.5 \pm 0.25$ & 0.66 & 99.33 \\
cream and onion & 80.0 & $79.4 \pm 0.17$ & 0.75 & 99.25 \\
flavor & 60.0 & $59.5 \pm 0.16$ & 0.83 & 99.16 \\
\hline & 35.0 & $34.4 \pm 0.21$ & 1.714 & 98.28 \\
Classic salted & 40.0 & $39.5 \pm 0.10$ & 1.250 & 98.75 \\
& 50.0 & $49.6 \pm 0.15$ & 0.80 & 99.20 \\
\hline \hline
\end{tabular}

${ }^{a}$ Mean \pm standard deviation

Ta b l e 5

Determination of Ni(II) in certified alloy samples

\begin{tabular}{|c|c|c|c|c|c|}
\hline Alloy sample & $\begin{array}{c}\text { Certified } \\
\text { composition }\end{array}$ & $\begin{array}{c}\text { Present }(\mathrm{ng} / \mathrm{ml}) \\
\mathrm{Ni}(\mathrm{II})\end{array}$ & $\begin{array}{c}\text { Found (ng/ml) } \\
\mathrm{Ni}(\mathrm{II}) \mathrm{a}\end{array}$ & $\begin{array}{l}\text { Relative } \\
\text { error } \%\end{array}$ & $\begin{array}{c}\text { Recovery } \\
\%\end{array}$ \\
\hline \multirow{3}{*}{ Constantan } & \multirow{3}{*}{$\mathrm{Cu} 60, \mathrm{Ni} 40$} & 80.0 & $79.80 \pm 0.05$ & 0.25 & 99.75 \\
\hline & & 40.0 & $39.81 \pm 0.10$ & 0.47 & 99.52 \\
\hline & & 100.0 & $99.70 \pm 0.05$ & 0.30 & 99.70 \\
\hline \multirow{3}{*}{ Monel wire } & \multirow{3}{*}{$\begin{array}{c}\mathrm{Ni} 60, \mathrm{Cu} 33, \mathrm{Fe} \\
6.5\end{array}$} & 48.0 & $47.76 \pm 0.10$ & 0.50 & 99.51 \\
\hline & & 32.0 & $31.85 \pm 0.05$ & 0.46 & 99.53 \\
\hline & & 120.0 & $119.7 \pm 0.07$ & 0.25 & 99.75 \\
\hline
\end{tabular}

${ }^{a}$ Mean \pm standard deviation 


\section{ACCURACY OF THE METHOD}

The accuracy of the described preconcentration method was tested in recovery studies by adding known amounts of $\mathrm{Ni}(\mathrm{II})$ to water samples and potato chip samples and also by the analysis of certified alloys containing Ni. The results obtained from the analysis of different samples are depicted in the tables and the recovery values were satisfactory. These results confirm the validity of the proposed method.

Table 6

\section{Comparison with other solid phase extraction methods}

\section{Comparison of the described method with some solid phase extraction methods for Ni(II) determination}

\begin{tabular}{|c|c|c|c|c|c|c|c|c|}
\hline $\begin{array}{l}\text { Impregnated } \\
\text { resin }\end{array}$ & Eluent & $\begin{array}{l}\text { Detection } \\
\text { technique }\end{array}$ & $\begin{array}{l}\text { Adsorbent } \\
\text { dose }(\mathrm{mg})\end{array}$ & $\mathrm{PF}^{a}$ & $\mathrm{pH}$ & Sample & $\begin{array}{c}\mathrm{RSD}(\%) / \\
\mathrm{DL}^{b}\end{array}$ & Ref. \\
\hline $\begin{array}{l}\text { 2-Aminothiazole } \\
\text { immobilized on silica gel }\end{array}$ & $2 \mathrm{M} \mathrm{HCl}$ & FAAS & 500 & 10 & -- & $\begin{array}{l}\text { Hydrated } \\
\text { fuel ethanol } \\
\text { samples }\end{array}$ & $3 / 2.3$ & 25 \\
\hline Chromosorb-107 resin & $\begin{array}{l}2.5 \mathrm{ml} \\
\text { of } 4.5 \mathrm{M} \\
\mathrm{HNO}_{3}\end{array}$ & ETAAS & 300 & 10 & $\geq / 6$ & $\begin{array}{l}\text { Apple leaves } \\
\text { and sea water } \\
\text { samples }\end{array}$ & $\pm 2 /--$ & 26 \\
\hline $\begin{array}{l}\text { Chitosan functionalized } \\
\text { with 3,4-dihydroxy- } \\
\text { benzoic acid }\end{array}$ & $\begin{array}{l}0.5 \mathrm{ml} \text { of } \\
2 \mathrm{M} \mathrm{HNO}_{3}\end{array}$ & $\begin{array}{l}\text { FI-ICP- } \\
\text { AES }\end{array}$ & -- & 11.8 & 5.5 & $\begin{array}{l}\text { River and sea } \\
\text { water samples }\end{array}$ & -- / 0.09 & 27 \\
\hline $\begin{array}{l}\text { Pyrocatechol violet } \\
\text { immobilized amberlite } \\
\text { XAD-2 }\end{array}$ & $\begin{array}{l}7.5 \mathrm{ml} \text { of } \\
4 \mathrm{M} \mathrm{HCl}^{-} \\
\mathrm{HNO}_{3}\end{array}$ & FAAS & 1000 & 18 & 3.0 & $\begin{array}{l}\text { Well water } \\
\text { samples }\end{array}$ & $\leq 9 /--$ & 28 \\
\hline $\begin{array}{l}\text { Chemically modified silica } \\
\text { gel with amino thio-amido } \\
\text { anthraquinone }\end{array}$ & $\begin{array}{l}5 \mathrm{ml} \text { of } \\
1 \% \mathrm{HNO}_{3}\end{array}$ & FAAS & 60 & 20 & $\geq 4$ & $\begin{array}{l}\text { Various water } \\
\text { samples }\end{array}$ & $\leq 9 / 2.9$ & 29 \\
\hline $\begin{array}{l}\text { Amberlite XAD- } \\
2 \text { functionalized } \\
\text { with 5-palmitoyl-8- } \\
\text { hydroxyquinoline }\end{array}$ & $\begin{array}{l}20 \mathrm{ml} \text { of } \\
2 \mathrm{M} \mathrm{HNO}_{3}\end{array}$ & FAAS & 1000 & 50 & $4.5-6.0$ & Water samples & $5.2 / 4.0$ & 30 \\
\hline $\begin{array}{l}\text { 1-(2-Pyridylazo)-2-naphthol } \\
\text { modified } \mathrm{SiO}_{2} \text { nanoparticles }\end{array}$ & $\begin{array}{l}5 \mathrm{ml} \mathrm{of} \\
6 \mathrm{M} \mathrm{HCl} \\
\end{array}$ & UV-VIS & 30 & 60 & 9.2 & Water samples & $4.1 / 0.43$ & 31 \\
\hline $\begin{array}{l}\mathrm{TiO}_{2} \text { nanotubes using } \\
\text { 8-hydroxy quinoline }\end{array}$ & $3 \mathrm{ml} \mathrm{HNO}$ & FAAS & 200 & 66.7 & 8.0 & Water samples & $2.6 / 1$ & 32 \\
\hline $\begin{array}{l}\text { 1-(2-Pyridylazo)-2-naphthol } \\
\text { immobilized on amberlite } \\
\text { XAD-1180 }\end{array}$ & $\begin{array}{l}20 \mathrm{ml} \text { of } \\
2 \mathrm{M} \mathrm{HNO}_{3}\end{array}$ & FAAS & 400 & 100 & 9.0 & Water samples & $\leq 8.5 / 1.2$ & 33 \\
\hline Activated carbon & $\begin{array}{l}2.5 \mathrm{ml} \\
\text { of } 1.5 \mathrm{M} \\
\mathrm{HNO}_{3}\end{array}$ & FAAS & 125 & 100 & 4.5 & $\begin{array}{l}\text { Natural water } \\
\text { samples }\end{array}$ & $9 / 0.6$ & 34 \\
\hline $\begin{array}{l}\text { Silica gel modified with } \\
\text { 3-aminopropyltriethoxy } \\
\text { silane }\end{array}$ & $\begin{array}{l}5 \mathrm{ml} \mathrm{of} \\
2 \mathrm{M} \mathrm{HCl}\end{array}$ & GFAAS & 500 & -- & $\geq 5$ & $\begin{array}{l}\text { Sea water } \\
\text { samples }\end{array}$ & $\pm 2 / 0.5$ & 35 \\
\hline $\begin{array}{l}\text { 1-(2-Pyridylazo)-2- } \\
\text { naphthol immobilized on } \\
\beta \text {-cyclodextrin butanediol } \\
\text { diglycidyl ether polymer }\end{array}$ & $\begin{array}{l}5 \mathrm{ml} \mathrm{of} \\
2 \mathrm{M} \mathrm{HCl}\end{array}$ & UV-VIS & 500 & 70 & 9.5 & $\begin{array}{l}\text { Water and } \\
\text { alloy samples }\end{array}$ & $<1 / 1.18$ & $\begin{array}{l}\text { This } \\
\text { work }\end{array}$ \\
\hline
\end{tabular}




\section{CONCLUSION}

The proposed preconcentration method consists of a simple and low-cost procedure which permits the quantitative recovery of $\mathrm{Ni}$ (II) from water and certified alloy samples. Based on the high affinity of the modified polymer for $\mathrm{Ni}(\mathrm{II})$, the selective determination of $\mathrm{Ni}(\mathrm{II})$ is possible. The preparation of the polymer is easy and the method has good accuracy, sensitivity and repeatability. The modified polymer was used in all the experiments performed for this study. It has a unique stability, is very economical and can be used repeatedly without a loss of sorption capacity. The resin is also durable against strong acids and concentrated bases. A resin used 10 times or more in succession did not lose its sorption efficiency. The relative standard deviation (RSD \%) of the method was $<1.0 \%$. The recoveries were $\geq 95 \%$ in all cases. The method provided a preconcentration factor of 70, which is higher than in most studies in the literature. The limit of quantification was $3.7 \mathrm{ng} / \mathrm{ml}$.

\section{REFERENCES}

[1] H. D. Belitz, W. Grosch, Food Chemistry, 2nd ed. Berlin, Springer, 1999.

[2] M.R. Jamali, Y. Assadi, R. R. Korana, F. Shemirani, Homogeneous liquid-liquid extraction method for selective separation and preconcentration of trace amounts of palladium, E-Journal of Chemistry, 6, 1077-1084 (2009).

[3] D. L. Giokas, E. K. Paleologos, M. I. Karayannis, Micelle-Mediated extraction of heavy metals from environmental samples: An environmental green chemistry laboratory experiment, J. Chem. Educ., 80, 61-64 (2003).

[4] S. Saracoglu, M. Soylak, Carrier element-free coprecipitation (CEFC) method for separation and pre-concentration of some metal ions in natural water and soil samples, Food Chem. Toxicol., 48, 1328-1333 (2010).

[5] A. N. Tang, D. Q. Jiang, X. P. Yan, Cloud point extraction preconcentration for capillary electrophoresis of metal ions, Anal. Chim. Acta, 507, 199-204 (2004).
[6] J. L. Anderson R. E. Sioda, Electro-deposition as a preconcentration step in analysis of multicomponent solutions of metallic ions, Talanta, 30, 627-629 (1983).

[7] M. R. Shishehbore, A. Afkhami, H. Bagheri, Salicylic acid functionalized silica-coated magnetite nanoparticles for solid phase extraction and preconcentration of some heavy metal ions from various real samples, Chem. Cent. J., 5, 41 (2011).

[8] A. Kaur, U. Gupta, Preconcentration of zinc and manganese using 1-(2-pyridylazo)-2-naphthol anchored $\mathrm{SiO}_{2}$ nanoparticles, Eurasian J. Anal. Chem., 4, 234-244 (2009).

[9] S. Tokalioglu, H. Buyukbas, S. Kartal, Preconcentration of trace elements by using 1-(2-pyridylazo)2-naphthol functionalized Amberlite XAD-1180 resin and their determination by FAAS, J. Braz. Chem. Soc., 17, 98-106 (2006).

[10] I. M. M. Kenaway, M. A. H. Hafez, M. A. Akl, R. R. Lashein, Determination by AAS of some trace heavy metal ions in some natural and biological samples after their preconcentration using newly chemically modified chloromethylated polystyrene-PAN ion-exchanger, Anal. Sci., 16, 493-500 (2000).

[11] I. Narin, M. Soylak, The uses of 1-(2-pyridylazo) 2-naphthol (PAN) impregnated Ambersorb 563 resin on the solid phase extraction of traces heavy metal ions and their determinations by atomic absorption spectrometry, Talanta, 60, 215-221 (2003).

[12] F. Shemirani, B. T. S. Akhavi, Preconcentration and determination of trace cadmium using 1-(2-pyridylazo)-2-naphthol (PAN) immobilized on surfactant-coated alumina, Anal. Lett., 34, 2179-2188 (2001).

[13] L. Yang, B. Hu, Z. Jiang, H. Pan, On-line separation and preconcentration of trace metals in biological samples using a microcolumn loaded with PAN-modified nanometer-sized titanium dioxide, and their determination by ICP-AES, Microchim. Acta, 144, 227-231 (2004).

[14] M. Tuzen, K. Parlar, M. Soylak, Enrichment/separation of cadmium(II) and lead(II) in environmental samples by solid phase extraction, J. Hazard. Mater., 121, 79-87 (2005).

[15] C. R. Preetha, T. P. Rao, Preparation of 1-(2-pyridylazo)-2-naphthol functionalized benzophenone/naphthalene and their uses in solid phase extractive preconcentration/separation of uranium(VI), Radiochim. Acta, 91, 247-251 (2003). 
[16] P. B. Barrera, M. A. Nancy, D. L. Cristina, B. B. Adela, Use of amberlite XAD-2 loaded with 1-(2-pyridylazo)-2-naphthol as a preconcentration system for river water prior to determination of $\mathrm{Cu}^{2+}, \mathrm{Cd}^{2+}$ and $\mathrm{Pb}^{2+}$ by flame atomic absorption spectroscopy, Microchim. Acta, 142, 101-108 (2003).

[17] D. Afzali, A. Mostafavi, Potential of modified multiwalled carbon nanotubes with 1-(2-pyridylazo)2-naphthol as a new solid sorbent for the preconcentration of trace amounts of cobalt(II) ion, Anal. Sci., 24, 1135-1140 (2008).

[18] D. Afzali, A. Mostafavi, Determination of trace amounts of $\mathrm{Cu}^{2+}, \mathrm{Ni}^{2+}$, and $\mathrm{Mn}^{2+}$ ions after preconcentration onto PAN-immobilized organo nanoclay as a new sorbent, J. AOAC Int., 91, 14301434 (2008).

[19] H. Tavallali, Determination of $\mathrm{Pb}(\mathrm{II})$ in some real samples based on alumina-coated magnetite nanoparticles solid phase extraction method, Int. J. Chem. Tech. Res., 3, 1641-1646 (2011).

[20] M. Komiyama, H. Hirai, Preparation of immobilized $\beta$-cyclodextrins by use of alkanediol diglycidyl ethers as crosslinking agents and their guest binding abilities, Polym. J., 19, 773-775 (1987).

[21] F. D. Snell, C. T. Snell, Colorimetric Methods of Analysis, New York, $3^{\text {rd }}$ ed., Van Nostrand, 1961.

[22] G. Yang, Q. Hu, Z. J. Huang, J. Yin, Study on the determination of lead, cadmium, mercury, nickel and zinc by a rapid column high-performance liquid chromatography, J. Braz. Chem. Soc., 16, 1154-1159 (2005).

[23] N. Pourreza, K. Ghanemi, Determination of copper by flame atomic absorption spectrometry after solid-phase extraction, Spectrosc. Lett., 39, 127134 (2006).

[24] M. Pasavento, R. Bieusz, M. Gallorini, A. Profumo, Sorption mechanism of trace amounts of divalent metal ions on a chelating resin containing iminodiacetate groups, Anal. Chem., 65, 2522-2527 (1993).

[25] P. S. Roldon, I. L. Alcantara, G. R. Castro, J. C. Rocha, C. C. F. Padilha, P. M. Padilha, Determination of $\mathrm{Cu}, \mathrm{Ni}$, and $\mathrm{Zn}$ in fuel ethanol by FAAS after enrichment in column packed with 2-aminothiazole-modified silica gel, Anal. Bioanal. Chem., 375, 574--577 (2003).

[26] S. Akman, N. Tokman, Determination of lead and nickel in apple leaves and sea-water by electro- thermal atomic absorption spectrometry after solid-phase extraction using Chromosorb-107 filled in a syringe, Talanta, 60, 199-204 (2003).

[27] A. Sabarudin, O. Noguchi, M. Oshima, K. Higuchi, S. Motomizu, Application of chitosan functionalized with 3,4-dihydroxy benzoic acid moiety for on-line preconcentration and determination of trace elements in water samples, Microchim. Acta, 159, 341-348 (2007).

[28] R. Saxena, A.K. Singh, Pyrocatechol violet immobilized amberlite XAD-2: synthesis and metal-ion uptake properties suitable for analytical applications, Anal. Chim. Acta, 340, 285-290 (1997).

[29] W. Ngeontae, W. Aeungmaitrepirom, T. Tuntulani, Chemically modified silica gel with aminothioamidoanthraquinone for solid phase extraction and preconcentration of $\mathrm{Pb}(\mathrm{II}), \mathrm{Cu}(\mathrm{II}), \mathrm{Ni}(\mathrm{II}), \mathrm{Co}(\mathrm{II})$ and Cd(II), Talanta, 71, 1075-1082 (2007).

[30] H. Filik, Metal ion preconcentration with amberlite xad-2 functionalized with 5-palmitoyl-8-hydroxyquinoline and its analytical applications, Anal. Lett., 35, 881-894 (2002).

[31] A. Kaur, U. Gupta, Preconcentration of nickel using chemically modified silica nanoparticles, Eurasian J. Anal. Chem., 4, 175-183 (2009).

[32] Q. Zhou, X. Zhao, J. Xiao, Preconcentration of nickel and cadmium by $\mathrm{TiO}_{2}$ nanotubes as solidphase extraction adsorbents coupled with flame atomic absorption spectrometry, Talanta, 77, 1774-1777 (2009).

[33] S. Tokalioglu, H. Buyukbas, S. Kartal, Preconcentration of trace elements by using 1-(2-pyridylazo)2-naphthol functionalized Amberlite XAD-1180 resin and their determination by FAAS, J. Braz. Chem. Soc., 17, 98-106 (2006).

[34] G. Kaya, I. Akdeniz, M. Yaman, Solid phase extraction and preconcentration of nickel in water samples with activated carbon-PAR and flame atomic absorption spectrometry, Atom. Spectroscop., 29, 150-155 (2008).

[35] N. Tokman, S. Akman, M. Ozcan, Solid-phase extraction of bismuth, lead and nickel from seawater using silica gel modified with 3-aminopropyltriethoxysilane filled in a syringe prior to their determination by graphite furnace atomic absorption spectrometry, Talanta, 59, 201-205 (2003). 
